\title{
Experiential Marketing Strategy: The Empirical Study
}

\author{
CHAO CHAO CHUANG \\ Hsing Wu University, New Taipei City 244, Taiwan \\ Email: chao5639@ms68.hinet.net
}

\begin{abstract}
In today's highly competitive and ever-changing world, companies need to take innovative experience design to present their brand to the customers. With experiential marketing, the managers should not only care about consumers' satisfaction. They should care more about making the customers emotionally attached to the product or service. By using different kinds of marketing channels, experiential marketing tries to engage all five senses (touch, taste, smell, sight, sound) to form a enjoyable experience, build connections and create consumers' loyalty.
\end{abstract}

Keywords: Experiential Marketing, Experiential Economy.

\section{Introduction}

Experiential marketing is a growing trend throughout the world. It is in all sectors of the global economy, from customer products such as automobile (Kerwin, 2018) to furniture products such as Ikea. It has become the foundation of many recent development in retailing, branding and marketing.

Experiential marketing includes the marketing of a product or service through an experience, so that the consumer becomes emotionally involved with the object of the experience. (Lantos, G. 2018) Experiential marketing provides customers tangible, interactive experiences and ample information, leading customers to make a purchase decision (McNickel, 2018).

Rather than providing the offer in a traditional method, through advertising media, for example, commercial and print, experiential marketing lets customers feel it by being part of it. Experiential marketing is an idea that integrates elements of emotions, logic, and usual thought processes to connect with consumers. (Malcolm Tatum, 2009) Attracting different kinds of senses, experiential marketing tries to inspire feeling about comfort and pleasure, as well as inspire the sense of practicality.

\section{Experiential Economy}

Experiential marketing was introduced by Pine and Gilmore (1998) as part of their work on experiential economy. Gilmore and Pine define experiential marketing as memorable events or experiences that engage the customer in a personal way. Thus, companies sell not just products but, more importantly, good memories and experiences. The profit companies obtain is significantly improved in the experiences stage compared with the commodity stage.

Goods markets improve on commodity markets by offering distinctive and tangibly different goods; service markets improve over goods markets by charging for extra activities that add value; transformation and 
experience markets take the improvement one step further and use technology and competitive forces to exceed the expectations of their customers by offering them differentiated products and experiences.

For instance, Singapore Airlines dressed its flight crew in batik clothes and created mini suites in the first section of their airliners to market a flight experience. Besides, McDonald added playgrounds to its restaurants to sell more than just "happy" meals for children. Developing marketing strategies which concentrate on creation of valuable experiences is becoming a key point for companies' success in the experience economy.

Successful businesses create loyal consumers by providing memorable experiences. Schmitt(1999) argued that experiences are formed from the interplay among different events and mental conditions. Prahalad and Ramaswany (2016) further suggested that creating personal experience would be the future competitive advantage for companies.

\section{Experiential Marketing vs. Traditional Marketing}

In contrast with conventional marketing method that concentrates on obtaining consumer satisfaction, experiential marketing creates emotional involvement. (McCole, P., 2019) Zaltman(2013) described that the sensory or emotional elements of the whole experience had greater effect on customer preferences than the features of product or service. The traditional marketing concerns sell a product's features, functional characteristics and performance but experiential marketing concentrates its efforts on the fantasies, feeling, fun, entertainment, fashion, and sense of excitement of the customer (Liu, 2017).

Schmitt(1999) argued that experiential marketing differed from traditional marketing in the following ways:

- Focus on customer experiences

Experiential marketing focuses on customer experiences. Experiences take place as an outcome of encountering, undergoing or living through situations. Experiences also connect the company and the brand to the customer's lifestyle. In sum, experiences provide sensory, emotional, cognitive, behavioral, and relational values that replace functional values. For example, traditional marketing might emphasize the price or cleanliness of their hotel rooms, while experiential marketing would stress the look and feel of the room and what it is like to stay there.

- Examine the consumption situation

The consumer evaluates how the product suits into the holistic consumption situation and the experiences offered by the consumption situation.

- Customers are rational and emotional

Conventional marketing views customers as rational decision-makers focusing on the functional features of products. For experiential marketers. consumers are emotional as well as rational. Though consumers often choose rationally, they are also frequently triggered by emotions because consumption experiences are often led toward pursuing pleasure, feelings and fun.

- Methods and tools are eclectic

The methods and tools of experiential marketing are multiple and multifaceted. It adopts a more diverse range of methods to attract customers. Tourist destination, for example, might be ideal topics for such fuzzy and esoteric research techniques. 
Moreover, Schmitt(1999) proposed experiential marketing was to create the sense, feel, think, act or relate experiential modules. Five experiential modules are defined as follows:

Sense experiential module: The sense marketing appeals to the customers with the objective creating sensory experiences, through sight, sound, touch, taste and smell. Attracting all five senses is very critical because the more sensory an experience is, the more memorable it will be. For example, Tiffany \& Co. sensory approach convey elegance with blue color. Food sampling and taste testing of different flavors of salad dressing, cooking seasoning, coolies and the like at supermarkets are examples of sensory experiential marketing, helping the customer to choose whether to buy them(Liu, 2017).

Feel experiential module: stimulate the customers' feeling on a particular brand name or product. The experience provider plans to link closely the experience, products and consumers by various methods. For example, Hagen-Dazs employs romantic themes to make their ice cream feel like a romantic indulgence. The slogans employed in military recruitment commercials appeal to a person's "pride in serving our country".

Think experiential module: intend to activate the innovative thinking of the consumers. It spurs consumers to think innovatively and to evaluate companies and products. Starbucks places great store by conducting its business responsibly and earning the trust and respect of its customers, employees, and neighbors, through initiatives such as ethical sourcing, environmental stewardship, community involvement, and shared planet issues.

Act experiential module: aimed at interacting with the others and physical experience. Schmitt suggests that consumers need extra motivation and stimulation, such as Nike and Adidas ads, which depended upon sports role models, LeBron James, Kobe Bryant, and Linsanity to showcase their commercial products.

Relate experiential module: relationship marketing appeals to an individual's need to interact and belong to others, a community or subculture which is often tied to symbolism attached to clothing, music and other visible affectations by members. For example, New York Yankees baseball team fans can shop for clothing with the Yankees logo on it; Harley-Davidson appeals to the rebellious biker image.

\section{Experiential Marketing Strategy}

\section{Experiential Marketing of Dental Products}

When launching new Sensodyne Complete Protection, GSK wanted to demonstrate how its technology can help sensitive teeth, as well as encouraging people to think more about sensitivity and its impact on their lives. 'The Great Sensitivity Test' was setup near London's Tower Bridge consisting of three different zones (David, 2014).

In the first, visitors found a free sensitivity check, complete with samples, prizes and demos; in the second, a colossal tooth-shaped sculpture ideal for some quick photo sharing; and in the third, the world's biggest oral hygiene demonstration, where over 230 people were given expert dental maintenance tips. This offbeat event marketing campaign saw Sensodyne hand out 6500 product samples, with 150 media mentions following this unique and informative event(The Events Structure, 2017).

Besides, GSK also holds the "Sensodyne Dental Health Spa" activity. Sensodyne's Dental Health Spa featured dental health professionals that provided oral hygiene education for consumers. The Dental Health Spa traveled to points of tooth sensitivity, fairs and festivals where enamel corroding food is plentiful.

Outside the Dental Health Spa consumers were encouraged to participate in various educational tooththemed games. Kids played a bean bag toss game in which they tossed high-acidic food-themed beanbags 
into an animated child's mouth, meanwhile brand ambassadors talked to the parents about proper hygiene for their child.

Consumers were invited inside the air-conditioned spa to receive a relaxing chair massage and refreshing chilled water while they waited to meet one-on-one with a certified Dental Hygienist in a private dental office themed area(Sensodyne, 2019).

Experiential marketing is to create an environment where the company can get the right consumer in the right place and at the right time. Presenting brand and visibility, Sensodyne engages future customers in an experience wrapped in a marketing message. Sensodyne creates much stronger memories.

\section{Experiential Marketing of Coffee Products}

Experiential marketing is significant for businesses, especially in the hospitality and tourism industry. Williams (2016) argued that products of this industry are always experiential. Besides products/services, people get experiences from staying at a hotel, eating in a restaurant, or going on a trip. Instead of purchasing new products that they do not have, customers want experience that they have never had.

Through meaningful and relevant experiences, experiential marketing connects consumers with the brand. It creates feelings and emotions. People purchase because they like to feel the experience of using the product. This can explain why customers pay a higher premium to shop at department stores rather than shopping mall. People like to buy a grande latte at Starbucks rather than just getting a cup of coffee from the convenience store 7-11. (Mayo Djakaria, 2017) Because Starbucks has promoted coffee consumption to a memorable experience. It tries to deliver the consumers a recreation of the Italian coffee shop experience. As has been noted, "every café is a stage".(Alistair Williams, 2016) By enriching people's lives, Starbucks reveals a message: the feeling of an experience is more powerful than its utility.

The "Starbucks experience" is different from others in the following aspects. First, in order to address the needs of the third space, Starbucks provide an appropriate place. Exactly, they do it. Starbucks carry out their motto: My café, my third life place. Maybe the first trip to Starbucks is due to its place, customers are attracted to its decoration of the store. Once they enter, they will be fascinated by the indoor atmosphere. Since then, customers love and enjoy Starbucks(Wu, 2018).

Second, Starbucks has produced the perfect product: Starbucks coffee. In order to make sure the highquality coffee, the staff of Starbucks do the good job from selecting the materials carefully to making coffee elaborately. Therefore, the customers have the opportunities to taste the perfect coffee.

Third, the staffs in Starbucks serve every customer's heart and soul. This makes for repeated purchase or repeated experience. Starbucks stresses to deliver positive and enjoyable service to its consumers. "More emotional, less rational" is the main marketing message promoted by Starbucks. This message is further conveyed by employees(Bigham L, 2017).

For customers, Starbucks brings not only good coffee but also a new idea of coffee experience (Chuang, 2018). Starbucks makes a third extraordinary place, to inspire, nurture and clean customer's mind, between home and work for conversation-a place for passionate service, and a sense of community.

Quite a number of customers go to Starbucks to enjoy the experience, including the welcoming atmosphere, high-quality coffee, graceful adornment, esthetic design, barista expertise and jazz music. Starbucks has invested much effort to create an excellent environment for experiential marketing strategy. Because the objective of experiential marketing is to design a stage for consumers to experience different stimulations(Michelli, 2017). 


\section{Experiential Marketing of Furniture Products}

Experiential marketing includes strategies such as distributing free product samples, providing free trial periods, and arranging events and tours that allow customers to use the products or services being marketed or to interact with sales representatives of the company. A survey by Jack Morton World shows that customers who experience and try new products or services have more positive opinions and attitudes about those products than those customers who know the product only through traditional advertising( such as television and print).

Ikea, the Swedish furniture company, believes strongly in experiential marketing to engage the customer emotionally.(Connie Lewis, 2018) In its stores, the eye-catching displays of furniture items and accessories create an imaginary lifestyle for the consumers. (FT.com. 2016) Ikea designs the whole room settings with different targets in mind. One maybe is more modern and another maybe is more traditional in style. Ikea lets consumers choose from differently decorated rooms, tracks which items are most popular, and makes in-store displays more attractive.

For instance, a bed on display might include a closet, rugs, a desk and other accessories. With simple, clean and comfortable bedroom furniture, Ikea evokes surprise and delight in customers' mind. Once customers see and touch the products, they get involved in the settings which will arouse customers' desire to purchase. Experiential marketing of eye-catching furniture displays works for any consumer on any sized budget. Ikea lets consumers actually experience the products prior to purchasing and delivers a more influential experience to consumers.

\section{Experiential Marketing of Car Products}

BMW is famous worldwide for innovative and luxurious cars. So, when the automotive brand wanted to promote its 7-series model, BMW brought to life the development process and engineering expertise behind the new BMW 7 Series Sedan.

Taking to flagship stores around the globe (including BMW Welt in Munich, the BMW brand stores in Paris and Brussels and the BMW Driving Centre in Seoul), BMW planned an elaborate experiential activity that used a combination of ground breaking technology and art, to attract consumers.

BMW is collaborating on the project with London-based agency Holition. The humanization of technology is a core value of Holition and it also became the key aim of this project throughout the bespoke projection mapping and face tracking application which emerged.

Holition used an advanced style of projection mapping to bring the overall design process of the model to life, by exhibiting a visually impressive video of it on to the side of the streamlined car. Ensuring the campaign was as impressive as possible, experts in the field of virtual reality and augmented reality seamlessly positioned each image pixel, to suit the real-life model perfectly(Joss, 2017).

Powerful projectors map perfectly-sized images onto a series model - from the first line drawing with the distinctive lines of the side profile, to clay models and 3D drawings. In the period of two minutes, visitors are able to understand the evolution of the BMW 7 Series - from idea to finished flagship. An additional screen provides further background information on the respective work stages(Zoe, 2017).

This campaign from BMW illustrates how exciting modern technology can be for experiential marketing. By using projection mapping to allow customers to see the overall design process of the 7-series, it further promoted BMW's brand essence that its vehicles are well made and can be trusted. Initiating brand loyalty, the futuristic feel to the campaign suggests that these traits will continue to lead the brand for many years to come. 


\section{Conclusion}

No single medium-television, print, Internet, or any other thing-is adequate to communicate with customers, especially considering the multitasking lifestyle so many customers lead. It is necessary to make the right mix of marketing tactics when trying to communicate with them.

Creativity and innovativeness will be characteristic of marketing in the twenty-first century. Experiential marketing is a commercial strategy that sometimes supplements or even displaces traditional media marketing. By concentrating on the events and activities that customers care about, and by reaching them when they are open to new ideas, managers can create relationships that develop emotional attachment to the brand.

Sensodyne helps potential consumers while they experience "The Great Sensitivity Test". Sensodyne offers a distinctive and instructive program to the customers while also displaying how its professionalism and products stand out from the competitors. Through experiential marketing, consumers learn to change their perspectives of Sensodyne and build a more long-term, loyal relationship- which is the eventual objective any experiential marketing program wants to achieve.

In the UK Ikea hosted a sleepover in its Essex store in response to a Facebook fan group called 'I wanna have a sleepover in Ikea'. Almost 100,000 people joined the group and Ikea gave 100 of them the chance to actually spend a night in the warehouse. The winners were given manicures and massages, and had a bedtime story read to them by a reality TV star. There was also a sleep expert on-hand to give people advice and potentially help them choose a new mattress. On the objective behind the Ikea, Ikea aims to assist customers to touch, feel and experience the products in a comfortable way. (David Moth, 2019)

Starbucks seeks to sell its coffeehouse experience by making the coffee buying experience not just about the coffee, but about the warm and inviting atmosphere of its shops, the interior spaciousness of its floor plans, and quaint touches such as its blackboard menus and countertops designs - all designed to be perceived as part of the art, aesthetics, and humanities of selling coffee(Liu, 2017).

BMW of North America is expanding its event marketing because 25 percent of participants who drove a vehicle later bought one. The Ultimate Driving Experience offers test drives-ranging from 30-minute street routes to high-speed race track instruction and teen driving classes - and a great evening for customers of BMW's most expensive vehicles.

Meanwhile, the Drive for Team USA will be held at 330 participating dealerships. Competitive vehicles are trucked in so prospective customers can compare an Audi, Mercedes-Benz or Lexus with a similar BMW model. Both events are part of BMW's experiential marketing plans that represent about 30 percent of the brand's annual marketing expenditure(Diana T. Kurylko, 2015). Other such plans include auto shows, golf, VIP owner and loyalty events. BMW's experiential marketing program shows people who turn out and buy -one out of every four do-and it has a positive increase on the brand.

Besides, BMW gets creative with projection mapping on 7-Series. Launched at BMW Welt in Munich, visitors have been attracted by a 2 minute projection mapped installation which tells the story of the 7 Series creative process. Holition created an innovative visual sequence which illustrates its intricate evolution from design inception to manufacture. It takes visitors on an educational journey showing the human craft involved in creating the technical blue prints and clay casting, to the machine craft involved in the engineering and build of such a luxurious and advanced car.

The project brings visitors closer to the BMW brand through new and interactive experiences. Besides, the project ideally combines ground breaking digital luxury storytelling and strong aesthetic appeal. This innovative approach to both content and medium suits BMW 7 Series perfectly(Kim, 2017). 
Nowadays, in today's highly competitive and ever-changing world, society is a huge experiential machine. The goods should contain the elements of experience and the process of shopping also needs. The pleasant experience through shopping process is the major trend of the marketing is the future. By using different kinds of marketing channels, experiential marketing tries to engage all five senses( touch, taste, smell, sight, sound) to form a enjoyable experience, build connections and create consumers' loyalty.

\section{References}

Alistair Williams(2016), Tourism and hospitality marketing: fantasy, feeling and fun International Journal of Contemporary Hospitality Management, 18(6), 2006

Bigham L. (2017), Experiential marketing: a consumer survey. New York: Jack Morton Worldwide. Available at: www.jackmorton.com/us/philosophy/whitePaper.asp.

Chuang, S.Y. (2018). The manager of Starbucks in Taiwan- Kuang Yu Hsu. Taipei, Taiwan: Foresight.

Connie Lewis.(2018). Marketer takes Ikea outdoors for a sensory sales experience. San Diego Business Journal, 29(20), 20.

David Moth(2019). 10 very cool examples of experiential marketing, available at https://econsultancy.com/blog/65230-10-very-cool-examples-of-experiential-marketing/

Diana T. Kurylko(2015). BMW expands event marketing after success in '14, available at http://www.autonews.com/article/20150511/RETAIL03305119998 /bmw-expands-event-marketingafter-success-in-14

FT.com.London (2016). The rise of experiential marketing. FT.com.London, 25 Sep. 2016

Kerwin, K.(2018). When the factory is a theme park. Business Week, 3 May.

Kim Benjamin(2017). Event TV: BMW uses projection mapping to bring Series 7 to life, available at http://www.eventmagazine.co.uk/event-tv-bmw-uses-projection-mapping-bring-series-7 life/brands/article/1422380

Kuang Tai Liu(2017). Starbucks experience explored in Taipei. The Journal of Human Resource and Adult Learning, 8(2), 107-116

Joss Davidge(2017). BMW's experiential campaign uses impressive projection mapping, available at https://www.becausexm.com/blog/ bmws-experiential-campaign -uses-impressive-projection-mapping

Lantos, G.(2018). Consumer behavior in action: Real-life applications for marketing managers. New York, NY: M.E. Sharpe.

Malcolm Tatum(2009). What is Experiential Marketing? http://www.wisegeek.com/what-is-experientialmarketing.htm

Mayo Djakaria(2017). The Starbucks Experience. Social Branding, 30 Sep.

McCole, P.(2019). Refocusing marketing to reflect practice : The changing role of marketing for business. Marketing Intelligence \& Planning, 22(5), 531-539.

McNickel, D. (2018). Hands on brands. May, available at:www.marketingmag.co.nz

Michelli, J.A. (2017). The Starbucks experience. New York: McGraw-Hill.

Pine, B.J. and Gilmore, J.H.(1998). Welcome to the experience economy. Harvard Business Review, July/August, 97-105.

Pine, B.J. and Gilmore, J.H.(1999). The experience economy. Harvard business School Press, Boston, MA, 1999.

Prahalad, C.K., \& Ramaswamy, V. (2016). Co-opting customer competence. Harvard Businsss Review, 78(1), 79-87.

Ritchie, B.J.R. et al.(2019). Tourism experience management research: Emergence, evolution and future directions. International Journal of Contemporary Hospitality Management, 23(4), 419-438.

Schmitt, B.(1999). Experiential marketing: How to get customer to sense, feel, think, act and relate to your company and brands. New York: The Free Press

Sensodyne(2019). Experience the Sensodyne Dental Health Spa, available at https://us.sensodyne.com/sensodyne-dental-health-spa.aspx

The Events Structure.(2017). Experiential Marketing: 5 Killer Campaigns, available at http://www.theeventsstructure.com/news/experiential-marketing-5-killer-campaigns 
Wu, Yung-Hung et al.(2018). The Research for the Taipei Starbucks Customer Demand of Coffee Chain Stores-Based on the Framework of Kano's Model and Experiential Marketing. Journal of Customer Satisfaction. Vol.4 No.1 March 2018.

Zaltman, G.(2013). How Consumers Think: Essential Insights into the Mind of the Market. Harvard Business School Press, Boston, MA, 2013.

Zoe Mutter(2017). BMW Projection Mapping and Innovative Storytelling, available at http://www.avinteractive.com/news/bmw-projection-mapping-and-innovative-storytelling-23-01-2017/
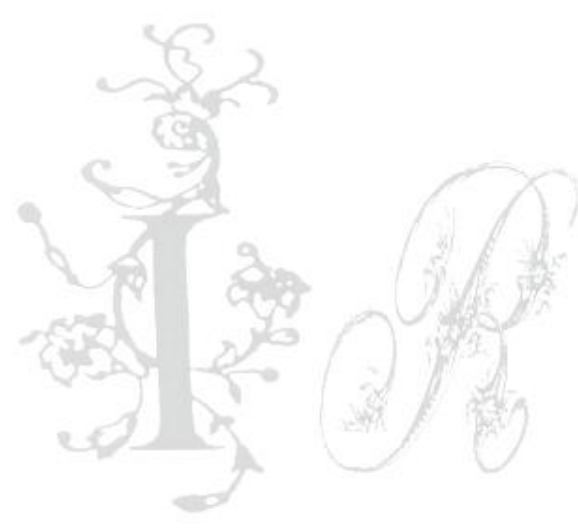